\title{
Teaching Video NeuroImages: Oculogyric crisis in treated Parkinson disease
}

Jennie L. Davis, DO, Julie A. Kurek, MD, John C. Morgan, MD, PhD, and Kapil D. Sethi, MD, FRCP

Neurology ${ }^{\circledR}$ 2018;90:e263. doi:10.1212/WNL.0000000000004816

A 52-year-old woman with Parkinson disease (PD) since age 42 on carbidopa/levodopa 25/ 2505 times/d developed "offs" characterized by left foot dystonia. After adding rasagiline $1 \mathrm{mg} /$ $\mathrm{d}$, multihour episodes of gaze deviation, anxiety, retrocollis, and dyskinesias ensued (video, links.lww.com/WNL/A30). Symptoms, marginally improved with diphenhydramine, resolved when levodopa was held temporarily. They did not recur after discontinuation of rasagiline.

Typical oculogyric crisis lasting hours with accompanying psychiatric features is rare in PD. ${ }^{1,2}$ It is more commonly associated with dopamine blockers, postencephalitic parkinsonism, and disorders of dopamine metabolism. ${ }^{1}$ Levodopa-induced brief suppressible gaze deviation, toward the side most affected in advanced PD, is more prevalent. ${ }^{2}$

\section{Author contributions}

Jennie Davis: study concept and design, acquisition of data, drafting and critical revision of manuscript for intellectual content. Julie Kurek: study concept and design, critical revision of manuscript for intellectual content. John Morgan: study concept and design, acquisition of data, critical revision of manuscript for intellectual content. Kapil Sethi: study concept and design, critical revision of manuscript for intellectual content.

\section{Study funding}

No targeted funding reported.

\section{Disclosure}

J. Davis reports no disclosures relevant to the manuscript. J. Kurek received speaker's honoraria from Teva. J. Morgan: consultant to Acorda, Impax, Lundbeck, Teva, Veloxis, and the National Parkinson's Foundation; speaker for Impax and Teva; research support from NIH and National Parkinson's Foundation; expert witness and consultant in various neurologic legal cases. K. Sethi: past employment: Merz Pharmaceuticals; consultant for Cynapsus and Teva Grant; support from the NIH, National Parkinson's Foundation, Kyowa, AbbVie, Acadia, Biotie, and Serina; expert witness in welding and metoclopramide litigation. Go to Neurology.org for full disclosures.

\section{References}

1. Slow EJ, Lang AE. Oculogyric crises: a review of phenomenology, etiology, pathogenesis, treat. Mov Disord 2017;32:193-202

2. Grotzsch H, Sztajzel R, Burkhard PR. Levodopa-induced ocular dyskinesia in Parkinson's disease. Eur J Neurol 2007;14:1124-1128.

\author{
Correspondence \\ Dr. Davis \\ Jennie_Davis@valleymed.org
}

\section{MORE ONLINE}

\section{$\oplus$ Video}

links.lww.com/WNL/A30

$\rightarrow$ Teaching slides:

links.lww.com/WNL/A223

From the Neuroscience Institute (J.L.D.), University of Washington-Valley Medical Center, Renton; and Movement Disorders Program, Department of Neurology (J.A.K., J.C.M., K.D.S.), Augusta University, Georgia.

Go to Neurology.org/N for full disclosures. 


\section{Neurology}

\section{Teaching Video NeuroImages: Oculogyric crisis in treated Parkinson disease}

Jennie L. Davis, Julie A. Kurek, John C. Morgan, et al. Neurology 2018;90;e263

DOI 10.1212/WNL.0000000000004816

\section{This information is current as of January 15, 2018}

Updated Information \& Services

References

Subspecialty Collections

Permissions \& Licensing

Reprints including high resolution figures, can be found at: http://n.neurology.org/content/90/3/e263.full

This article cites 2 articles, 0 of which you can access for free at: http://n.neurology.org/content/90/3/e263.full\#ref-list-1

This article, along with others on similar topics, appears in the following collection(s):

Parkinson's disease/Parkinsonism

http://n.neurology.org/cgi/collection/parkinsons_disease_parkinsonism

Information about reproducing this article in parts (figures,tables) or in its entirety can be found online at:

http://www.neurology.org/about/about_the_journal\#permissions

Information about ordering reprints can be found online:

http://n.neurology.org/subscribers/advertise

Neurology ${ }^{\circledR}$ is the official journal of the American Academy of Neurology. Published continuously since 1951 , it is now a weekly with 48 issues per year. Copyright Copyright $(92018$ American Academy of Neurology. All rights reserved. Print ISSN: 0028-3878. Online ISSN: 1526-632X.

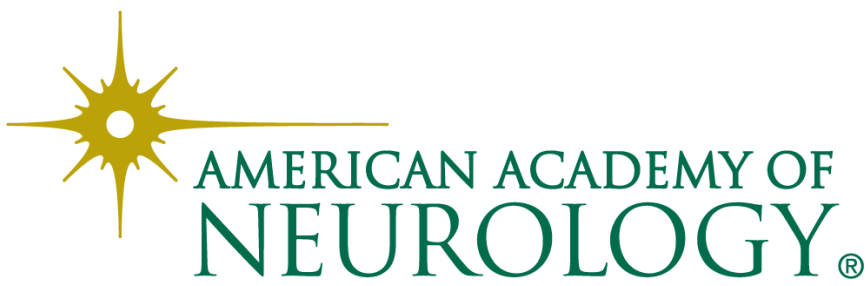

